ECONOMIC THEMES (2018) 56(4): 453-473

S sciendo

DOI 10.2478/ethemes-2018-0026

\title{
AN ECONOMETRIC ANALYSIS OF THE EFFECTS OF HUMAN RESOURCES AND OTHER FACTORS ON FIRM CREATION
}

\author{
Matea Zlatković
}

University of Banja Luka, Faculty of Economics, Banja Luka

Bosnia and Herzegovina

$\triangle$ matea.zlatkovic@ef.unibl.org

UDC

005.94:

519.862

Original scientific paper

Received:

16.07.2018

Accepted:

28.12.2018

\begin{abstract}
Intangible assets and knowledge are key drivers of today's economy, called knowledge economy, as a consequence of globalisation process and information and communication technology development. Knowledge and intellectual capital became leading factors that provide basis for gaining superior performance and sustainable competitive advantage of firms in dynamic and uncertain business environments. Invisible goods based on knowledge are becoming more important in generating and successful managing businesses. The purpose of this research is to test the impact of human resources on creation of the firm or, in other words, to examine individual's inclination toward becoming an entrepreneur in transition economy such as Bosnia and Herzegovina. While investigating the relationship between human resources and firm creation, additional social, economic and emotional factors are included in analysis. Proposed theoretical model is tested using logistic regression model to analyse a sample of 2.015 individuals in Bosnia and Herzegovina, as a participant in GEM project in 2014. Obtained results show that the amount of individual's knowledge, skills and expertise and its capability to seek and recognize new entrepreneurial opportunities, considered as human resources owned by individual, increase probability to generate a firm in Bosnia and Herzegovina. Beside human resources, certain economic and social factors, such as work status and social perception of entrepreneurship as an attractive profession, are important for firm creation in Bosnia and Herzegovina.
\end{abstract}

Keywords: knowledge economy, transition economy, human resources, firm creation, logistic regression model

JEL classification: C25, M13 


\section{Introduction}

Many studies suggest that entrepreneurship has positively influenced economic prosperity and growth (Ács, Szerb \& Autio, 2011; Arenius \& Minniti, 2005; Bosma, 2013). Some authors believe that entrepreneurship enhances productivity, growth and innovation (Van Praag \&Versloot, 2007). It is important to consider which factors encourage or disable individuals from generating new ventures. Potential entrepreneurs are affected by their environment through motivations and perceptions, formulating their propensity and attitudes that determine behaviour. The growing interest is presented toward generating new ventures for which is expected to nurture social and economic development. Some authors are stimulated to apply concept of the intellectual capital to studies about firm creation and entrepreneurship. Particular interest is focused on considering the role of the intellectual capital in cases of science parks and business incubators (Schiavone et al., 2014; Calza et al., 2014) and some of them investigated intellectual capital with reference to creating new ventures (Hayton, 2005; Hormiga et al., 2011; Musteen \& Ahsan, 2013). It is evident that researches on relationship intellectual capital - start-up are more pronounced.

The purpose of this research is to test the impact of human resources, as an element and base of intellectual capital, on individual's decision to create a firm or, in other words, to examine individual's inclination toward becoming an entrepreneur. Along with human resources owned by individual, additional economic, social and emotional factors as predictors of individual's intention to create a firm are observed. The triggers of a firm creation cannot be considered using only objective measures such as age, gender, income level, educational level, etc. Perceptual measures such as individuals' knowledge, skills and feelings are included in proposed theoretical model. This approach is considered new, particularly in process of firm creation in transition country context and it is coherent with previous approaches that simultaneously include both certain demographic and economic attributes and perceptual factors referring to entrepreneur (Arenius \& Minniti, 2005).

Current research seeks to broaden and enrich the studies about influence of the human resources on intention to generate a firm.

In the next section, the theoretical framework used for empirical analysis is presented and hypotheses are formulated. According to hypotheses, the authors examined whether and how human resources and certain social, economic and emotional factors influence individual's decision to start a business. Hypotheses are defined in line with well-known theories for the objectives of this research. Further, some methodological aspects of the research are described, such as: sample characteristics, measurement of variables and findings as outcomes of tested hypotheses. Finally, in conclusion, the results obtained are summarised, some limitations of the current study indicated and implications for policymakers and directions for future researches are given. 


\section{Theoretical framework and hypotheses}

\subsection{Start-up expectations}

Considering the abovementioned aim of the study, it is important to determine the dependent variable in proposed theoretical model. Dependent variable that describes individual's decision to generate a firm is called start-up expectation. This dependent variable determines the propensity that aspiring entrepreneurs show toward starting new ventures. Many researchers are interested in studying propensity of individuals toward entrepreneurship (Ajzen, 1991; Krueger et al. 2000). There is significant difference between entrepreneurs and non-entrepreneurs considering their propensity toward entrepreneurship. Start-up expectations represent a proxy variable for measuring inclination toward starting new venture.

\subsection{Human resources as an element and fundament of intellectual capital}

Intellectual capital as a bundle of intangibles can be considered as a source from which new ventures create their competitiveness, enhance profitability and create value. Recently, many scholars are paying more attention to intellectual capital investigation (Petty \& Guthrie, 2000; Bontis, 1999, 2000; Hormiga et al., 2011). Intangible resources represent factors that do not have characteristic of financial and physical resources. They contribute to process of value creation (Bontis, 1999). Nowadays, intellectual capital and intangible resources are main factors that define profitability and success of the firms. When the term of intellectual capital was first mentioned by John Kenneth Galbraith (1969), as a form of intellectual contribution provided by individuals to ensure success of new venture, many authors became interested in this concept. There are many areas where an intellectual capital concept can be used from business strategies to production management (Petty \& Guthrie, 2000). The general agreement is that intellectual capital is composed of intangible resources and it is used as instrument for creating value in knowledgeintensive business (Khalique et al., 2015).

Different models of intellectual capital and different intellectual capital classifications for measurement purposes are proposed. The OECD (1999) proposes human and structural capital as elements of intellectual capital. Human capital refers to resources within and outside venture. Structural capital relates to non-human storage of knowledge, used information systems and process in organisations. Beside this, there is another broadly accepted classification of intellectual capital according to which intellectual capital implies distinction between external (customer), internal (structural) and human capital (Bontis et al., 2000). According to Brooking (1996), intellectual capital contains market assets, human-centred assets, intellectual property and infrastructural assets. In recent period, a few studies have been examining the relationship between human 
resources and firm creation in different economic context (Arafat \& Saleem, 2017; Matriciano, 2016; Ramos-Rodrigez et al., 2010, 2012). There are no similar studies, known by author, that have measured this relationship in the context of transition economy such as Bosnia and Herzegovina.

Knowledge, skills and experience - Perception of the risk is moderate and depends on the individuals' confidence into their skills and knowledge. Individual can be capable to handle high risk situations if he or she perceives them lower than they actually are. This is possible due to level of confidence that certain individual has in its capability to address the risk. While examining the role of acquiring skills and knowledge through experience, skills and knowledge are not so difficult to acquire in tourism which enables entries (Szivas, 2001). As suggested by theory of planned behaviour (Ajzen, 1991), individuals' beliefs in their capabilities, knowledge and skills that are fundamental to generate a firm will influence their perception of themselves as those who have control of their behaviour. These individuals can have positive attitude toward entrepreneurial behaviour. If a potential entrepreneur believes more that he or she will generate a firm, the greater probability that entrepreneur will act in the right way to realise this goal.

In order to test the effect of knowledge, skills and experiences on expectations to start a business, the owned knowledge, skills and experience by aspiring entrepreneurs can be used as an approximate variable of entrepreneurs' human resources. The hypothesis begins thus:

- Hypothesis 1. The more entrepreneurs are convinced that they own the necessary knowledge, skills and experience to start their business, the higher their start-up expectations are.

Entrepreneurial opportunities - In cases when individuals are trying to notice if there any business opportunities, they are actually validating their level of confidence in economic surrounding (Maula et al., 2003). If the obtained results are positive then individual's attitude toward entrepreneurial way of conduct is favourable, according to theory of planned behaviour (Ajzen, 1991). Numerous business opportunities in close environment determine ability of entrepreneur to identify business opportunities. Entrepreneur has a special alertness used to seek and spot opportunities that are not recognised by other individuals (Kirzner, 1979). While facing with particular business opportunities in environment, alertness ability allows entrepreneurs to perceive opportunities better than other nonentrepreneurs.

In order to test the relevance of the business opportunities recognition for expectations to start $\mathrm{u}$ business, recognition of new entrepreneurial opportunities can be used as an approximate variable of entrepreneurs' human resources. Following hypothesis is: 
- Hypothesis 2. The more entrepreneurs are convinced that they are able to recognise new entrepreneurial opportunities, the higher their start-up expectations are.

Relationships with other entrepreneurs - Personally knowing other entrepreneurs can create positive attitudes toward entrepreneurs and positively affect individual's propensity to create a firm (Maula et al., 2003), as indicated in theory of planned behaviour (Ajzen, 1991). There are many empirical studies that suggest the significance of the positive relationship between indirect experience and inclination to generate a firm. Knowing other entrepreneurs improves individuals' perception in their ability to control certain actions in order to create a firm. Thus, the perception of control is more emphasised than in case when potential entrepreneur does not know any entrepreneurs. Acquaintance with other entrepreneurs influences subjective norms of potential entrepreneur and his start-up expectations. As the role theory (Veciana, 2007) suggests, individuals' acquaintance with entrepreneurs from their surroundings can provide easier collection of information that increase the possibility of firm creation and make firm's success more credible. From network theory perspective, social relations can give to entrepreneur fundamental information and ideas to start a business (Larson \& Starr, 1993). Relationships with other entrepreneurs will provide new contacts and an access to other entrepreneurs of interest to the entrepreneur's start-up.

Finally, in order to test the relevance of the social networks for expectations to start a business, knowing established entrepreneurs who own and manage their businesses can be used as an approximate variable of entrepreneurs' human resources. Following hypothesis is:

- Hypothesis 3. Knowing other entrepreneurs increases the start-up expectations.

Furthermore, analysis includes tests whether individual's age, gender, and educational level or not influence entrepreneurial behaviour of a potential owner of the firm.

Gender - There are many studies that suggest that men establish more firms compared to women (Reynolds et al., 2003; Arenius \& Minniti, 2005) even though it appears that there are no significant psychological differences between them (Langowitz \& Minniti, 2005). It seems that their management styles and entrepreneurial aims are different.

\section{- Hypothesis 4. Being male is positively related to the start-up expectations.}

Age - There are studies that have analysed the relationship between intention to create firm and age. Some authors revealed that entrepreneurs tend to be young, in the age between 25 and 34 years, but established entrepreneurs are usually older (Reynolds et al., 2003; Blanchflower, 2004). It is indicative that individual's startup expectations are directly related to how young they are. The intention is to determine whether entrepreneurial start-up expectations decline with age. 
Demographic evolution of developed countries and population's ageing are key reasons for existence of this phenomenon (Weber \& Schaper, 2004).

- Hypothesis 5. The older the potential entrepreneurs, the lower their start-up expectations.

Education level - Individual's confidence in their skills is not necessarily related to the education level. Several studies indicate that many entrepreneurs possess a variety of skills while at the same time having no higher levels of education. Certain findings indicate positive relationship between education level and firm generation in developed economies (Blanchflower, 2004). Different countries have different education systems and various definitions of the term entrepreneur. In case of high-tech firms' creation, entrepreneurs might need a high educational level. On the other hand, a high educational level is not necessary precondition for entrepreneurs that have just found themselves in right time at the right place to spot the business opportunity and exploit it.

There is greater probability that higher level of education suggests the greater capability to control (Maula et al., 2003), as indicated by theory of planned behaviour (Ajzen, 1991). The level of education can contribute to individuals' belief that they possess a satisfying level of capability to create a successful firm.

- Hypothesis 6. The education level is positively related to the start-up expectations.

According to some authors, some of the abovementioned variables of human resources such as: knowledge, skills and experience, entrepreneurial opportunities and relationships with other entrepreneurs, can be considered as proxy variables of intellectual capital and social capital (Ramos-Rodrigez et al., 2010, 2012; Matriciano, 2016; Arafat \& Saleem, 2017).

\subsection{Economic, social and emotional factors}

Many studies provide a lot of evidence to support the existence of the relationship between socio-economic factors and intention to start a firm. Also, the effect of the tendency toward risk and fear of failure on an entrepreneurial behaviour is examined.

Household income - Individuals with a high level of income can distribute their household income in a wider range of investments, including those which are risky (Maula et al., 2003). Some authors determined that net wealth and income level are important factors of the amount of household income invested in risky assets (Gollier, 2002).

Work status - Many studies determined that there is greater probability that employed individuals will generate a firm compared to those individuals who do not work (Arenius \& Minniti, 2005). It is not yet clear whether unemployment discourages or encourages individuals to create a firm as a way to raise their income (Blanchflower, 2004). According to incubator theory, many business ideas 
and projects turn classic worker into entrepreneur in the working environment. The marginalisation theory confirms that marginalisation encourages individuals to generate firms. Probability of firm creation increases with unemployment and bad working conditions (Evans \& Leighton, 1989).

Perception of social acknowledgment - Favourable attitude toward certain kind of behaviour, in this case start-up expectation, is influenced by social norms according to theory of planned behaviour (Ajzen, 1991). If individuals perceive something as acceptable by society, it will affect their inclination to create a business. Facts on whether people perceive entrepreneur as an attractive profession or not, and whether entrepreneurs have a high social status and prestige or not are included by social environment factors. According to abovementioned, hypotheses are determined as follows.

- Hypothesis 7. Economic and social factors influence start-up expectations.

- Hypothesis 7a. The higher the household income, the higher the start-up expectations.

- Hypothesis $7 b$. Works status is positively related to the start-up expectations.

- Hypothesis 7c. The society's perception of being an entrepreneur as an attractive profession has a positive relationship with start-up expectations.

- Hypothesis 7d. The society's perception of entrepreneurs as individuals who have high status and prestige is positively related to the start-up expectations.

Fear of failure - Some authors describe the fear of failure as a negative emotion $(\mathrm{Li}, 2011)$ that has negative influence on intentions to start a firm. The theory of appraisal of emotions defines emotions as type of responses that are in accordance to individual's judgment of specific events in the external surrounding. According to this theory, fear of failure as emotional state increases the intention to launch new venture. Some authors consider that the fear of failure limits entrepreneurial intentions (Cacciotti \& Hayton, 2015).

According to the theory of planned behaviour (Ajzen, 1991), the fear of failure controls individual ability to create a firm which generates unfavourable attitude toward this kind of behaviour. Risk aversion and fear of failure are closely related. Higher risk aversion leads to higher fear of failure. According to the trait theory (Collins\& Moore, 1964), entrepreneurs prefer moderate risk. Hypothesis 8 is determined as follows:

- Hypothesis 8. The lower the fear of failure, the higher the start-up expectations.

\section{Research methodology}

In order to fulfil the purpose of this research, all data are used from Global Entrepreneurship Monitor (GEM) project. Research hypotheses are tested using a 
sample size of 2.015 respondents (18-64 years old) collected for 2014 for Bosnia and Herzegovina. Data are obtained from Adult Population Survey (APS). There is no possibility to test all variables as in previous researches because GEM questionnaire does not contain all items relevant to entrepreneurial intention. Nevertheless, some of them can be examined. Details about the procedures used to collect and harmonise GEM data can be found in Reynolds et al. (2005). Moreover, the survey provides data on 343 variables; in this work those variables which are coherent to the objectives of the study are selected.

\subsection{Operationalisation of variables and econometric model}

The dependent variable is start-up expectations which indicate the inclination or propensity toward entrepreneurship and venture creation. The start-up expectations variable is measured by dichotomous variable that has value 1 if the respondent provides affirmative answer to the question „Are you, alone or with others, expecting to start a new business, including any type of self-employment, within the next three years", and 0 otherwise.

Human resources of the entrepreneurs examined here are: knowledge, skills and experience, entrepreneurial opportunities, relationships with other entrepreneurs, gender, age and educational level. Knowledge, skills and experience are measured by dichotomous variable that has value 1 if the respondent provides the affirmative answer to the question "Do you have the knowledge, skill and experience required to start a new business?", and value 0 otherwise. Entrepreneurial opportunities are measured by dichotomous variable that has value 1 if the respondent provides affirmative answer to the question „In the next six months, there will be good opportunities to start up new businesses in the area where you live.", and value 0 otherwise. Relationships with other entrepreneurs are measured using a dichotomous variable equal to 1 if the respondent responds affirmatively to the question „Do you know someone personally who has started up a new business in the past two years?", and 0 otherwise. Gender represents dichotomous variable that has value 0 for males and 1 for females. Age is measured by continuous variable in years. To assess educational level, the respondents were asked to determine the highest education that they possess, while their responses were categorised as variable from five categories. These categories are as follows: "none", "some secondary", "secondary degree", "postsecondary", and "university bachelor's degree or higher".

Perceptual variable is used to measure individual's emotional state and aversion to risk. Fear of failure is measured by dichotomous variable that has value 1 if the respondent provides affirmative respond to the question "Would fear of failure prevent you from starting a business?", and value 0 otherwise.

In order to provide better understanding of background which encourages or discourages firm creation and improvement of individual's skills, knowledge and 
capabilities to recognise business opportunities and build ties and connections among current and potential entrepreneurs, additional social and economic factors are included such as: household income, work status, social status and attractive profession. Household income consists of three categories. The possible response categories are as follows: "lowest 33 percentile", "middle 33 percentile" and "upper 33 percentile". The household income category called "lowest 33 percentile" is used as the reference category.

Work status consists of six categories. The response categories were: "full or part time", "part time only", "retired, disabled", "homemaker", "student", "not working, other". In the logistic regression analysis, the last income group is used as the reference category. In the logistic regression analysis, the first group is used as the reference category.

Perception of social acknowledgment is measured using two dichotomous variables: social status and attractive profession. Social status is measured using dichotomous variable that has value 1 if the respondent provides affirmative answer to the question „In my country, those successful at starting a new business have a high level of status and respect", and value 0 otherwise. Attractive profession measured using a dichotomous variable that has value 1 if the respondent provides affirmative answer to the question „In my country, most people consider starting a new business a desirable career choice", and value 0 otherwise.

Econometric model - Specification: the objective of this research is to examine impact of certain number of independent variables (explanatory variables) on a dependent variable. So, in this research the general logistic regression model is applied. Procedure provided by Hosmer and Lemeshow (2000) is followed through process of the model estimation. Specification of the model is as follows:

$$
P(Y=1)=\frac{1}{1+e^{-(\beta X)}}
$$

where $\mathrm{X}$ represents a vector which includes all abovementioned explanatory variable, $\beta$ represent the vector of unknown parameters of the regression model measuring effect of each explanatory variable on the probability that dependent variable, endogenous variable start-up expectations takes value 1 given the $\mathrm{X}$ observed variables.

Model estimation - Parameters of the model indicated by the vector $\mathrm{X}$ are evaluated applying the maximum likelihood function as loss function. Presence of the collinearity issues between variables in the model is inspected observing values from the correlation matrix.

Verification - Verification of the model is performed using likelihood ratio test. Furthermore, the Hosmer-Lemeshow test is used and the share of the correct classifications of the observed values is compared to the values which are predicted by the model. The statistical significance of the model parameters is verified using 
Wald's test. Also, the odds ratio is determined to provide enough information to interpret obtained results.

Exploitation - The main objective of the use of the estimated model is to determine the importance of the regression coefficients, their sign and to recognise the important factors than to predict the dependent variable.

\section{Results and discussion}

Certain indicators of descriptive statistics and level of correlation between variables of the model are presented in Table 1. As it can be seen, correlation coefficients do not have high values. This indicates that there is low possibility that multicollinearity issues to appear, which can generate undesired effects on the estimated parameters. Majority of correlation coefficients are significant. It is important to have in mind that their significance can be misleading in case of large sample sizes that characterise lower dispersion of the sample distributions and smaller correlation coefficients can be near critical value and statistically significant (Rubin, 2010).

The number of missing cases in this model represents those cases where there is no response to one or several questions (Table 2).

Table 2. Missing cases

\begin{tabular}{|l|l|r|r|}
\hline \multirow{2}{*}{ Unweighted Cases $^{\mathrm{a}}$} & $\mathrm{N}$ & \multicolumn{2}{|}{ Percent } \\
\hline \multirow{3}{*}{ Selected Cases } & Included in Analysis & 1396 & 69,3 \\
\cline { 2 - 4 } & Missing Cases & 619 & 30,7 \\
\cline { 2 - 4 } & Total & 2015 & 100,0 \\
\hline Unselected Cases & 0 & 0,0 \\
\hline Total & 2015 & 100,0 \\
\hline
\end{tabular}

af weight is in effect, see classification table for the total number of cases.

\section{Source: Authors' calculation}

Results of the omnibus test (Table 3), that tests the null hypothesis that all estimated parameters of the estimation model are equal to zero in contrast to the alternative hypothesis that at least one estimation parameter is not zero, suggest that the null hypothesis can be rejected at $1 \%$ significance, hence goodness of fit of the model is acceptable.

Table 3.Omnibus tests on model coefficients

\begin{tabular}{|l|l|r|r|r|}
\hline & & Chi-square & df & \multicolumn{2}{|c|}{ Sig. } \\
\hline Step 1 & Step & 200 & 19,0 & 0 \\
\hline & Block & 200 & 19,0 & 0 \\
\hline & Model & 200 & 19,0 & 0 \\
\hline
\end{tabular}

Source: Authors' calculation 


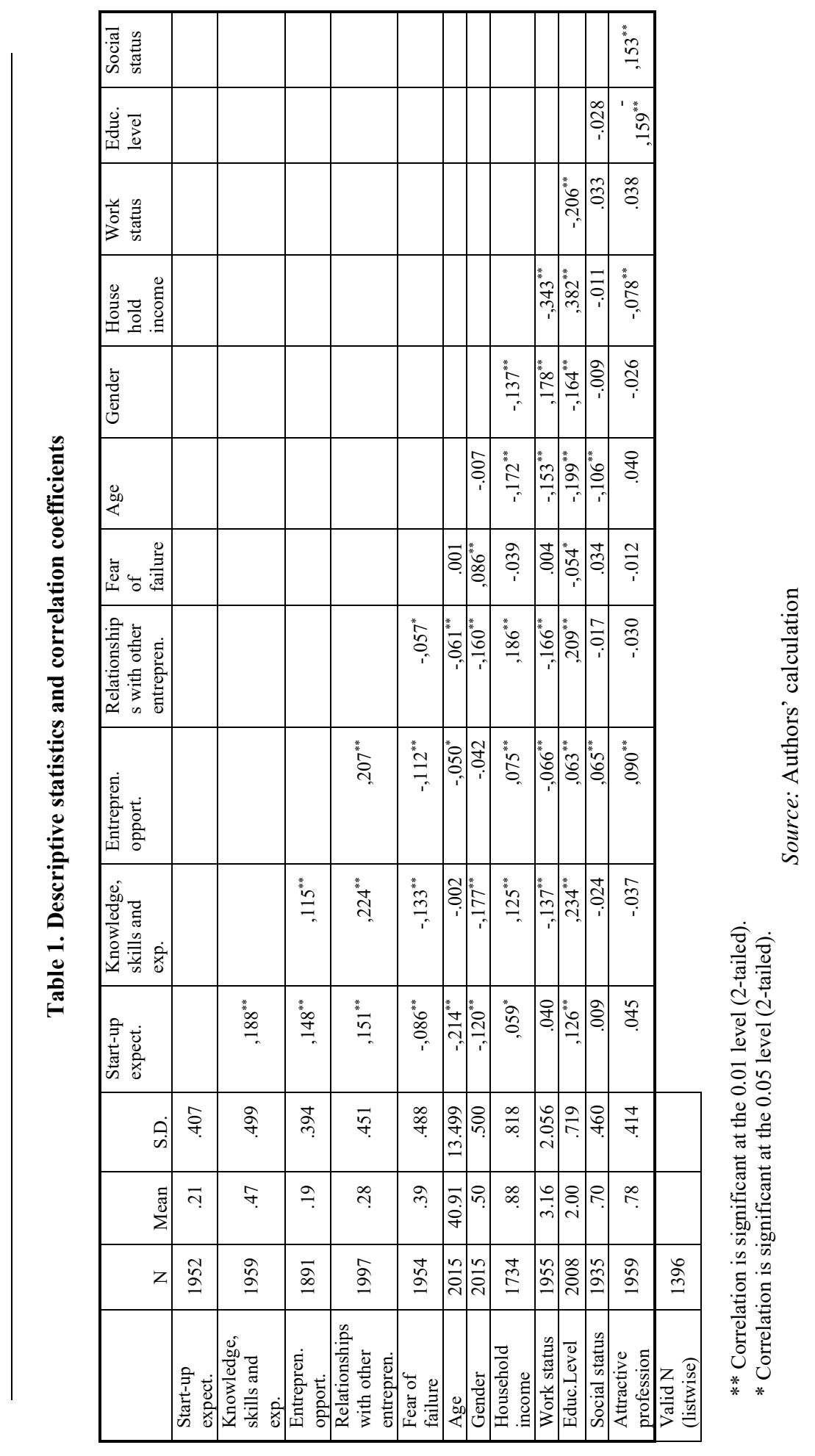


In order to test the extent to which predicted and observed probabilities match, in way that high values of the probability in prediction model is related to the result $\mathrm{Y}=1$ in the response variable, the Hosmer and Lemeshow goodness-of-fit test is used. The hypothesis of an adequate model fit is accepted if the probability is higher than 0.05. The obtained model has an acceptable fit (Table 4).

Table 4. The results of the Hosmer and Lemeshow goodness-of-fit test

\begin{tabular}{|l|l|l|lr|}
\hline Step & Chi-square & Df & Sig. & \\
\hline 1 & 7,188 & 8 & 0,516 \\
\hline
\end{tabular}

Source: Authors' calculation

Results of the logistic regression which includes all variables are presented in Table 5. Among economic and social factors, following variables are significantly different from zero: work status and attractive profession.

While examine significance of human resources of entrepreneurs, it can be concluded that knowledge, skills and experience and entrepreneurial opportunities have statistical significant effects on start-up expectations. The relationship between start-up expectations and each of these human resources is positive. Knowledge, skills and experience have the strongest positive effect on intention to start a business (0.708). Individual's belief in owning adequate skills and knowledge in order to generate a business is significant for propensity to create a business. The odds ratio for this variable is 2.030 . Thus potential entrepreneurs who feel capable to generate a firm are nearly two times more likely to create it than others. Obtained results are similar to results of other studies about different types of entrepreneurs which indicate that someone's confidence in possession of the appropriate ability to start a business is the most significant factor in deciding to create business (Arenius \& Minniti, 2005). Hypothesis 1 is confirmed.

Entrepreneurial opportunities have the second strongest positive effect on startup expectations (0.572). Hypothesis 2 is confirmed. Exchange of and improving knowledge that is not created through routines or dynamic capabilities of the firm because they do not exist in start-ups yet, can lead to knowledge creation represented in new entrepreneurial possibilities. It is created through recognition, discovery and creation. According to the neoclassical view, entrepreneurial opportunities are already present in the economic surrounding but to be discovered entrepreneurs have to own specific capabilities such as alertness (Kirzner, 1973). Entrepreneurs have important part because it is necessary for them to own certain abilities to detect new entrepreneurial opportunities. So, initial assumption is that the discovery of the entrepreneurial opportunity is not related to the aspiring entrepreneur nor the surrounding. They are regarded as a third-person opportunity (McMullen \& Shepherd, 2006). They are possible opportunities for someone. Individuals who own capabilities to perceive opportunities are nearly 1.8 times 
ready to start a business. These results provide support for the observed hypothesis. Obtained results coincide with those of other studies that examine this relationship between different types of entrepreneurs and provide support for Kirzner's theory. This theory indicates that carefulness is a necessary part of the opportunity recognition.

Table 5. The logistic regression model's estimation

\begin{tabular}{|c|c|c|c|c|c|c|c|c|c|}
\hline & \multirow[t]{2}{*}{ B } & \multirow[t]{2}{*}{ S.E. } & \multirow[t]{2}{*}{ Wald } & \multirow[t]{2}{*}{ Df } & \multirow[t]{2}{*}{ Sig. } & \multirow{2}{*}{$\begin{array}{l}\text { Exp } \\
\text { (B) }\end{array}$} & \multicolumn{2}{|c|}{$\begin{array}{l}\text { 95\% C.I. } \\
\text { for } \operatorname{EXP(B)}\end{array}$} \\
\hline & & & & & & & & Lower & Upper \\
\hline \multirow[t]{23}{*}{$\begin{array}{l}\text { Ste } \\
\mathrm{p} 1^{\mathrm{a}}\end{array}$} & $\begin{array}{l}\text { Knowledge, } \\
\text { skills and exp. }\end{array}$ & ,708 & , 147 & 23,062 & 1 &, 000 & 2,030 & 1,521 & 2,711 \\
\hline & $\begin{array}{l}\text { Entrepren. } \\
\text { opport. }\end{array}$ &, 572 & , 166 & 11,806 & 1 &, 001 & 1,772 & 1,278 & 2,455 \\
\hline & $\begin{array}{l}\text { Relationships } \\
\text { with other } \\
\text { entrepren. }\end{array}$ & ,277 & , 152 & 3,296 & 1 &, 069 & 1,319 & ,978 & 1,778 \\
\hline & Fear of failure &,- 255 & , 146 & 3,049 & 1 & 081 & ,775 & ,583 & 1,032 \\
\hline & Age &,- 031 & ,007 & 22,413 & 1 & ,000 & 970 & ,957 & ,982 \\
\hline & Gender &,- 353 &, 150 & 5,506 & 1 & ,019 & ,703 & ,523 & ,944 \\
\hline & $\begin{array}{l}\text { Household } \\
\text { income }\end{array}$ & & &, 844 & 2 & ,656 & & & \\
\hline & $\begin{array}{l}\text { Middle } 33 \\
\text { percentile }\end{array}$ & 145 &, 174 & ,693 & 1 & ,405 & 1,156 &, 822 & 1,624 \\
\hline & $\begin{array}{l}\text { Upper } 33 \\
\text { percentile }\end{array}$ &, 020 & ,193 &, 010 & 1 & ,919 & 1,020 & ,699 & 1,488 \\
\hline & Work status & & & 26,900 & 5 & ,000 & & & \\
\hline & $\begin{array}{l}\text { Full: full or part } \\
\text { time }\end{array}$ &,- 509 & ,183 & 7,701 & 1 &, 006 & ,601 & ,420 &, 861 \\
\hline & Part time only & ,474 & ,263 & 3,244 & 1 & ,072 & 1,606 & ,959 & 2,690 \\
\hline & $\begin{array}{l}\text { Retired, } \\
\text { disabled }\end{array}$ & $-1,096$ &, 356 & 9,461 & 1 &, 002 &, 334 & , 166 & ,672 \\
\hline & Homemaker &,- 845 & ,356 & 5,638 & 1 & ,018 & ,430 & ,214 & , 863 \\
\hline & Student &,- 226 & ,284 &, 632 & 1 & ,427 & ,798 & ,457 & 1,392 \\
\hline & Educ.level & & & 9,057 & 4 &, 060 & & & \\
\hline & Some secondary &,- 533 & ,630 & ,714 & 1 & ,398 & ,587 & ,171 & 2,019 \\
\hline & $\begin{array}{l}\text { Secondary } \\
\text { degree }\end{array}$ & ,194 &, 571 & ,116 & 1 &, 734 & 1,215 & ,396 & 3,722 \\
\hline & Post-secondary & ,307 & ,595 & ,267 & 1 & ,606 & 1,360 & ,423 & 4,365 \\
\hline & $\begin{array}{l}\text { Bachelor's } \\
\text { degree or higher }\end{array}$ &,- 846 &, 820 & 1,066 & 1 &, 302 & ,429 & ,086 & 2,139 \\
\hline & Social status &,- 225 & ,156 & 2,075 & 1 &, 150 & ,799 & ,588 & 1,084 \\
\hline & $\begin{array}{l}\text { Attractive } \\
\text { profession }\end{array}$ & ,388 & , 178 & 4,766 & 1 & ,029 & 1,474 & 1,040 & 2,089 \\
\hline & Constant &,- 354 & ,681 & ,270 & 1 & ,604 & ,702 & & \\
\hline
\end{tabular}

Source: Authors' calculation 
Relationships with other entrepreneurs, as form of human resources of entrepreneurs, do not have significant influence on start-up expectations. This result is inconsistent with hypothesis 3. Thus, knowing established entrepreneurs and possibilities to capture facts and new ideas through social exchange with them to create a firm and being successful entrepreneur is insignificant in observed research context. Being solo entrepreneur that owns necessary knowledge and skills with specific capabilities to recognise or discover new entrepreneurial opportunities is more important for firm creation. Opposite to results of this research, some studies reveal that acquaintance with established entrepreneurs has positive impact on generating business. Being a part of the certain social networks can reduce uncertainty and ambiguity and improve information sharing, personal contacts and resources, and importance of entrepreneurs (Veciana, 2007).

The regression coefficient of gender has a negative sign which is in line with Hypothesis 4 . The odds ratio for this variable is 0.703 which indicates that there is lower probability for women to create a firm compared to men. This result is consistent with results of other studies that test gender and its role in nascent entrepreneurship (Reynolds et al., 2003; Arenius \& Minniti, 2005). As a product of different process of learning and socialiszation, women could be perceived as less entrepreneurial self-efficient with more pronounced fear of failure and lower ability to recognise business opportunities than men. Women's entrepreneurial behaviour is limited. Understanding entrepreneurship as masculine career choice in Bosnia and Herzegovina could lead to these obtained results.

Coefficient of the variable age is negative (-.031), which suggests that the probability of creating start-up wanes with age. This result confirms Hypothesis 5, and it is in accordance with similar studies related to gender issues and different types of entrepreneur (Arenius \& Minniti, 2005).

The categories of educational level have insignificant values compared to reference category no education. These results are not consistent with hypothesis 6 . It can be concluded that educational level does not have importance in the context of Bosnia and Herzegovina, even though other studies reveal that high educational level increases ability to identify and exploit opportunities for starting the business. Knowledge and skills related to start-up intentions are not necessarily linked to the formal education. Some authors give support to obtained results claiming that successful entrepreneurs frequently own a broad range of abilities, natural talent and skills but do not possess any higher education in certain area (Murphy et al, 1991; Leazar, 2002). Some authors have found that education does not have any effect on entrepreneurial intentions (Ahmed, et al. 2010, Tornikoski \& Kautonen 2009). In Bosnia and Herzegovina, entrepreneurship can be often seen as a form of self-employment and as product of unsuccessful rent-seeking in occupations for which individuals have completed their formal education. These results could indicate that different education and training systems in Bosnia and Herzegovina have not yet included (or not enough) into their programmes appropriate tools to 
encourage the entrepreneurial way of thinking and develop necessary entrepreneurial capabilities needed to create a firm.

The influence of the economic and social factors on start-up expectations is confirmed, in certain amount, so hypotheses $7 \mathrm{~b}$ and $7 \mathrm{c}$ are partly or fully accepted.

Household income is irrelevant to possibility to create a firm. Hypothesis $7 \mathrm{a}$ is rejected. These findings are inconsistent with previous studies (Maula, 2003). Some authors obtained similar results as those in this research (Arafat \& Saleem, 2017). These findings may be related to start-up configurations. Some studies revealed that entrepreneurs who engage in start-ups in cooperation with other individuals creating start-up teams have greater access to variety of attractive financing options than the amount of options available to other firms' configurations (solo entrepreneurs and family start-ups) and may rely less on household income (Nunez, 2015). Furthermore, in Bosnia and Herzegovina personal resources are very low, so many potential entrepreneurs often use outside debt and equity financing as alternatives to personal savings.

Variable work status does not show a clear statistical significance. Work status as a whole variable has a coefficient significantly different from zero. Hypothesis $7 \mathrm{~b}$ is partially confirmed. Only categories full or part time, retired, disabled and homemaker have clear negative relation with intention to start a business. This means that categories full or part time, retired, disabled and homemaker are less likely to start business than does who do not work at all. Category retired, disabled has the strongest effect on start-up expectations. The retired, disabled have lower probability to create a firm compared to reference category (not working). The probability of this variable is 0.672 that suggests that retired, disabled are nearly $30 \%$ less likely to generate a firm compared to those who do not work. Homemakers have lower probability to create a firm compared to reference category. The odds ratios for categories homemaker (0.863) and full or part time (0.861) indicate that homemakers and full or part time employed are nearly $14 \%$ less likely to start a business compared to those who do not work.

Only one of two perceptual variables of social acknowledgment is statistically significant - attractive profession. Hypothesis $7 \mathrm{~d}$ about high social status and prestige for those who successfully start a business is rejected. On the other hand, hypothesis $7 \mathrm{c}$ is confirmed. Social perception about being an entrepreneur as an attractive profession is positively associated to the inclination to generate a firm. Perception of being an entrepreneur as an attractive profession increases by nearly $50 \%$ the probability of individual's intention to start a business (odds ratio $=1.474$ ). This finding is consistent with theory of planned behaviour (Ajzen, 1991) regarding whether type of attitude toward certain way of behaviour is influenced by social norms. Whether particular kind of behaviour is regarded as socially acceptable and favourable or not, affects individuals' propensity to generate a business. 
The fear of failure does not have a significant influence on start-up expectations. Hypothesis 8 is rejected. This result is not consistent with findings related to different types of entrepreneur (Arenius \& Minniti, 2005). These latter authors revealed that high perception of risk decreases propensity toward starting business.

\section{Conclusion}

The growing scientific interest is showed toward firm creation from which is expected to boost social and economic growth and enhance prosperity. These claims are leading many researchers to apply the concept of intangibles to entrepreneurial intentions models. Theory of planned behaviour argues that attitudes, subjective norms, and perceived feasibility of individual affect its intentions in general, and as consequent influence entrepreneurial intentions represent as type of these intentions (Ajzen, 1991). Knowledge, skills, experience and education as attributes of human capital can strengthen the individual cognitive capabilities to discover opportunities and provide information base to obtain judgments toward new business creation. Professional networks, friends and family members enrolled in business and personal acquaintance with entrepreneurs as attributes of social capital are sources of information and support in firm creation.

This research represents an attempt to provide understanding how human resources influence the decision to start a business from socio-economic perspective in transition country such as Bosnia and Herzegovina. This study is preliminary effort to understand the human resources and socio-economic and emotional factors that influence individual's inclination toward entrepreneurship. To author's knowledge, there are no studies that have tested the relationship between abovementioned factors and entrepreneurial intention in the Bosnia and Herzegovina. Empirical analysis uses GEM data and represent some form of scientific contribution to deeper analysis of firm creation phenomenon in transition countries. In this research, intention to start a business is analysed as a function of human resources owned by potential entrepreneur. In attempt to obtain more accurate and deeper findings, some additional economic, emotional and social factors are also included in the analysis.

Theoretical model is estimated using logistic regression model which is appropriate considering types of indicators used for measuring variables. This econometric model is based on assessment of the impact of chosen variables on a dependent variable called start-up expectations.

Individuals who own skills and knowledge and who are self-confident are most ready to create a business. Also, the second most important factor that defines probability of starting business is capability of individuals to perceive good entrepreneurial opportunities in their close environment. The obtained results do 
not empirically suggest that higher educational level influence the intention to start a business in the Bosnia and Herzegovina. Exchange of information and encouragement and facilitation of the relationships between entrepreneurs and those who want to become entrepreneurs, are not important for intention to create a business in case of Bosnia and Herzegovina. Older individuals who are men are more likely to become an entrepreneur in Bosnia and Herzegovina. Obtained results suggest two useful implications for managers and policymakers. They should direct their activities on providing necessary support to population to develop the skills and knowledge to generate a business. So, knowledge obtained through formal educational process is not as important as practical and professional knowledge and skills in order to increase intention to become an entrepreneur and to own and manage its own business. At the same time, policy makers should create a stimulating environment that would enhance the capabilities of the potential entrepreneurs to better recognise or create new entrepreneurial opportunities and incorporate in education systems necessary tools to encourage entrepreneurship. Uncertainty in business success or fear of failure and established networks with other entrepreneurs are not so important for propensity to start up. Entrepreneurship is still seen as masculine career choice so certain efforts in culture and social area have to be made to induce women to become entrepreneurs. Policy makers should focus on above-mentioned actions to encourage potential entrepreneurs to create firms.

Research findings indicate that age, gender and certain categories of work status such as full or part time, retired, disabled and homemaker influence the intention to create a business. Consequently, individuals are more likely to create a firm when they are younger and male and not working compared to those who work full or part time, retired ones and those who work at home. Individuals who are retired and/or disabled are most unlikely to start a business.

Beside some of the abovementioned demographic and economic factors, it is important to consider whether entrepreneurial activity is perceived as favourable or unfavourable behaviour by society. Someone's perception of the firm creation is majorly affected by social norms which further encourage or discourage this kind of behaviour. So an entrepreneurial intention to start-ups will be influenced by its social acceptance. Also, one more perceptual variable is included in analysis called the fear of failure to test whether uncertainty and the fear of failure lead to perception that individual is not able to control the behaviour needed to create a firm. Interesting result of this research is that only perceiving the profession of entrepreneur as attractive affects the decision to become an entrepreneur.

In future research, it is recommended to perform longitudinal study for Bosnia and Herzegovina to gain more comprehensive insights into the relationship between human resources and start-ups from socio-demographic and economic perspective. Also, differences in outcomes of the proposed theoretical model between types of industries would shed more light on existence and significance of 
relationship between human resources and firm creation. Further investigations could propose additional, more specific measures of the entrepreneurs' personal traits such as leadership, motivation, innovativeness, originality and flexibility. Also, it would be useful to test this model on other transition countries and to compare obtained results that would provide valuable information on how to nurture individual's confidence in skills and knowledge, improve ability to discover new entrepreneurial opportunities and establish networks and support closer communication among entrepreneurs. This could lead to enhancement of entrepreneurial mind set and perception of entrepreneurship as form of selfemployment. Differences between countries that have different economic development stages such as factor-driven, efficiency-driven and innovation-driven (Bosma \& Levie, 2010) could provide interesting insights into relationship between human resources and firm creation phenomenon and propose directions to follow to obtain higher levels of development and economic prosperity.

\section{References}

Ács, Z. J., Szerb, L., \& Autio, E. (2011). Global entrepreneurship and development index 2011 (Vol. 400). Cheltenham, UK/Northampton MA, US: Edward Elgar.

Ahmed, I., Nawaz, M. M., Ahmad, Z., Shaukat, M. Z., Usman, A., Rehman, W. U., \& Ahmed, N. (2010). Determinants of students' entrepreneurial career intentions: Evidence from business graduates. European Journal of Social Sciences, 15(2), 14-22.

Ajzen, I. (1991). The Theory of Planned Behavior. Organizational Behavior and Human Decision Processes, 50 (2), 179-211.

Arafat, M. Y., \& Saleem, I. (2017). Determinants of entrepreneurial startups in India: A study using GEM data. In S. Misra, S. Shukla, \& G. Batthini (Eds.), Twelfth biennial conference on Entrepreneurship.Paper presented at twelfth biennial conference on entrepreneurship, entrepreneurship development Institute of India, Ahmedabad 22-24 February (656-665). Delhi: Bookwell.

Arenius, P., \& Minniti, M. (2005). Perceptual variables and nascent entrepreneurship. Small business economics, 24(3), 233-247.

Blanchflower, D. G. (2004). Self-employment: More may not be better (No. w10286). National Bureau of Economic Research.

Bontis, N., Dragonetti, N.C., Jacobsen, K. \& Roos, G. (1999). The knowledge toolbox: a review of the tools available to measure and manage intangible resources. European Management Journal, 17(4), 391-402.

Bontis, N., Keow, W.C.C., \& Richardson, S. (2000). Intellectual capital and business performance in Malaysian industries. Journal of Intellectual Capital, 1(1), 85-100.

Bosma, N., \& Levie, J. (2010). Global Entrepreneurship Monitor: 2009 Global Report. Global Entrepreneurship Research Association.

Bosma, N. (2013). The global entrepreneurship monitor (GEM) and its impact on entrepreneurship research. Foundations and Trends ${ }^{\circledR}$ in Entrepreneurship, 9(2), 143-248.

Brooking, A. (1996). Intellectual capital. Cengage Learning EMEA.

Calza, F., Dezi, L., Schiavone, F., \& Simoni, M. (2014). The intellectual capital of business incubators. Journal of Intellectual Capital, 15(4), 597-610.

Cacciotti, G., \& Hayton, J. C. (2015). Fear and Entrepreneurship: A review and research agenda. International Journal of Management Reviews, 17(2), 165-190. 
Collins, O., \& Moore, D.G. (1964). The Enterprising Man. Michigan State University Press, East Lansing, MI.

Evans, D. S., \& Leighton, L. S. (1989). Some empirical aspects of entrepreneurship. The American Economic Review, 79(3), 519-535.

Galbraith, J. K. (1969). The New Industrial State. Harmondsworth: Penguin.

Gollier, C. (2002). What does the classical theory have to say about household portfolios? Household portfolios, 27-54.

Hayton, J.C. (2005). Competing in the new economy: the effect of intellectual capital on corporate entrepreneurship in high-technology new ventures. $R \& D$ Management, 35(2), 137-155.

Hormiga, E., Batista-Canino, R.M. \& Sánchez-Medina, A. (2011). The role of intellectual capital in the success of new ventures. International Entrepreneurship and Management Journal, 7(1), 71-92.

Hosmer, D. W., \& Lemeshow, S. (2000). Applied Logistic Regression, 2nd ed.(Wiley: New York.). NY, USA.

Khalique, M., Bontis, N., Shaari, J.A.N. \& Isa, A.H.B. (2015). Intellectual capital in small and medium enterprises in Pakistan. Journal of Intellectual Capital, 16(1), 224-238.

Kirzner, I.M. (1979). Perception, Opportunity, and Profit. University of Chicago Press, Chicago.

Krueger, N.F.Jr., Reilly, M.D., \& Carsrud, A.L. (2000) Competing models of entrepreneurial intentions. Journal of Business Venturing, 1(5-6), 411-432.

Langowitz, N., \& Minniti, M. (2005). Gender Differences and Nascent Entrepreneurship. Working Paper.

Larson, A., \& Starr, J.A. (1993). A network model of organization formation. Entrepreneurship Theory and Practice, 17(2), 5-16.

Leazar EP (2002). Entrepreneurship. NBER Working Paper, No. 9109.

Li, Y. (2011). Emotions and new venture judgment in China. Asia Pacific Journal of Management, 28(2), 277-298.

Matricano, D. (2016). The impact of intellectual capital on start-up expectations. Journal of Intellectual Capital, 17(4), 654-674.

Maula, M., Autio, E., \& Arenius, P. (2003). What drives micro-angel investments? A large sample study of the factors explaining micro-angel investments. Working Paper Series 91-WP2003-001, Espoo, Finland.

McMullen, J.S. \& Shepherd, D. (2006). Entrepreneurial action and the role of uncertainty in the theory of the entrepreneur. Academy of Management Review, 31(1), 132-152.

Minniti, M. (2004). Entrepreneurial alertness and asymmetric information in a spinglass model. Journal of Business Venturing, 29 (5), 637-658.

Murphy, K. M., Shleifer, A., \& Vishny, R. W. (1991). The allocation of talent: Implications for growth. The quarterly journal of economics, 106(2), 503-530.

Musteen, M. \& Ahsan, M. (2013). Beyond cost: the role of intellectual capital in off-shoring and innovation in young firms. Entrepreneurship Theory and Practice, 37(2), 421- 434.

Nunez, E. (2015). The differing impact of household income on firm emergence by heterogeneous start-up configuration. New England Journal of Entrepreneurship, 18(2), 31-46.

Petty, R. \& Guthrie, J. (2000). Intellectual capital literature review: measurement, reporting and management. Journal of Intellectual Capital, 1(2), 155-176.

Ramos-Rodriguez, A. R., Medina-Garrido, J. A., Lorenzo-Gómez, J. D., \& Ruiz-Navarro, J. (2010). What you know or who you know? The role of intellectual and social capital in opportunity recognition. International Small Business Journal, 28(6), 566-582.

Ramos-Rodríguez, A. R., Medina-Garrido, J. A., \& Ruiz-Navarro, J. (2012). Determinants of hotels and restaurants entrepreneurship: A study using GEM data. International Journal of Hospitality Management, 31(2), 579-587. 
Reynolds, P.D., Bygrave, B., \& Hay, M. (2003). Global Entrepreneurship Monitor Report. E.M. Kauffmann Foundation, Kansas City, MO.

Rubin, A. (2010). Statistics for Evidence-based Practice and Evaluation. Brooks/Cole, Cengage Learning, Belmon, USA.

Schiavone, F., Meles, A., Verdoliva, V. \& Del Giudice, M. (2014). Does location in a science park really matter for firms' intellectual capital performance?Journal of Intellectual Capital, 15(4), 497-515.

Tornikoski, E. T., \& Kautonen, T. (2009). Enterprise as sunset career? Entrepreneurial intentions in the ageing population. International Journal of Entrepreneurship and Small Business, 8(2), 278-291.

Van Praag, C. M., \& Versloot, P. H. (2007). What is the value of entrepreneurship? A review of recent research. Small Business Economics, 29(4), 351-382.

Veciana, J. M. (2007). Entrepreneurship as a scientific research programme. In Entrepreneurship (pp. 23-71). Springer, Berlin, Heidelberg.

Weber, P., Schaper, M., 2004. Understanding the grey entrepreneur. Journal of Enterprising Culture 12 (2), 147-164.

\section{EKONOMETRIJSKA ANALIZA EFEKATA LJUDSKIH RESURSA I DRUGIH FAKTORA NA STVARANJE PREDUZEĆA}

Apstrakt: Nematerijalna imovina i znanje su ključni pokretači današnje ekonomije zvane ekonomija znanja, što je posledica procesa globalizacije i razvoja informacionih i komunikacionih tehnologija. Znanje i intelektualni kapital postaju vodeći faktori koji pružaju osnovu za postizanje superiornih performansi i održive konkurentske prednosti preduzeća širom sveta, u dinamičnom i neizvesnom poslovnom okruženju. Povećava se značaj nematerijalnih proizvoda zasnovanih na znanju za stvaranje i uspešno upravljanje preduzećima. Cilj ove studije je da testira uticaj ljudskih resursa na odluku pojedinca da stvori preduzeće. Drugim rečima, cilj je da se ispita sklonost pojedinca da postane preduzetnik u tranzicionoj ekonomiji, kao što je Bosna i Hercegovina. Pored istraživanja odnosa ljudskih resursa i stvaranja preduzeća, ispitan je i uticaj sociodemografskih, ekonomskih i emocionalnih faktora. Predloženi teorijski model se testira korišćenjem modela logističke regresije, kako bi se analizirao uzorak od 2.015 pojedinaca u Bosni i Hercegovini koji su učestvovali u GEM projektu 2014. godine. Dobijeni rezultati pokazuju da obim znanja, veština i stručnosti pojedinca i njegova sposobnost da traži i prepoznaje nove preduzetničke mogućnosti, kao aspekti ljudskih resursa, povećavaju verovatnoću stvaranja preduzeća u Bosni i Hercegovini. Pored ljudskih resursa, određeni ekonomski i društveni faktori poput radnog statusa i društvene percepcije preduzetništva kao atraktivne profesije su važni za stvaranje preduzeća u Bosni i Hercegovini.

Ključne reči: ekonomija znanja, tranziciona ekonomija, ljudski resursi, stvaranje preduzeća, model logističke regresije 


\section{Authors' biography}

Matea Zlatković is a $\mathrm{PhD}$ student at the Faculty of Economics, University of Belgrade. She completed undergraduate studies in 2010 at the Faculty of Economics, University of Banja Luka, as the best student in the generation. After obtaining her master degree at the same faculty, she enrolled in doctoral studies at the Faculty of Economics, University of Belgrade. Now she is working on a doctoral dissertation in the field of knowledge economy and structural equation modeling. She has been working at the Faculty of Economics in Banja Luka since 2011, as senior assistant. Her scientific research interests are: knowledge economy, entrepreneurship and behavioral economics, microeconomics and applied econometrics and statistics. 